Original Research Paper

\title{
Pelatihan Program Parenting untuk Meningkatkan Profesionalisme Guru PAUD Di Kota Mataram Tahun 2018
}

\author{
Fahruddin $^{1 *}$, Baiq Nilawati Astini' \\ ${ }^{1}$ PG PAUD Jurusan Ilmu Pendidikan Fakulas keguruan dan Ilmu Pendidikan, Universitas Mataram
}

*Corresponding Author: Fahruddin, PG PAUD Jurusan Ilmu Pendidikan Fakulas keguruan dan Ilmu Pendidikan, Universitas Mataram, Indonesia; Email: fahruddin.fkip@unram.ac.id

\begin{abstract}
Abstrak: Pendidikan anak usia dini sangat penting artinya untuk perkembangan anak selanjutnya, sehingga pelatihan program parenting untuk meningkatkan profesionalisme guru PAUD dibutuhkan kompetensi guru profesional meliputi kemampuan guru mengenal peserta didik yang dilayaninya secara mendalam. Tujuan yang ditargetkan dalam pengabdian kepada masyarakat ini adalah Terbangunnya pengetahuan dan pemahaman guru atau pendidik PAUD pentingnya program parenting di sekolah, meningkatnya keterampilan guru atau pendidik PAUD dalam mengembangkan program parenting di sekolah/PAUD, tersusunnya program parenting di sekolah masing-masing sesuai dengan kondisi dan terimplementasikannya program parenting di sekolah/PAUD di sekolah masingmasing Untuk itu dalam mewujudkan kegiatan tersebut perlu untuk dilakukan dengan memberikan pelatihan mengenai program pengasuhan/parenting kepada guru-guru PAUD/TK di-kota mataram. Dalam pelatihan itu akan diberikan pengetahuan secara teoritis dan praktis. Pengetahuan teoritis berkenaan dengan gambaran umum tentang strategi belajar mengajar dengan menggunakan pendekatan parenting tanpa memperhatikan perbedaan bidang ilmu yang digelutinya. Sedangkan kegiatan praktisnya akan dilaksanakan dengan pemberian tugas latihan kepada peserta sesuai dengan bidang ilmunya masing-masing. Dalam kegiatan latihan akan dilakukan pembimbingan oleh anggota tim, sampai pada setiap peserta menghasilkan kegiatan yang menggunakan program parenting.
\end{abstract}

Kata Kunci: Program Parenting, Propesionalisme Guru

\section{Pendahuluan}

Kompetensi guru profesional meliputi kemampuan guru mengenal peserta didik yang dilayaninya secara mendalam, menguasai bidang studi secara keilmuan dan kependidikan dalam hal mengemas materi pembelajaran, kemampuan menyelenggarakan pembelajaran yang mendidik mulai dari perancangan sampai pemanfaatan hasil penilaian terhadap proses dan hasil pembelajaran serta pengembangan profesionalitas yang berkelanjutan. Namun beberapa hasil penelitian memperlihatkan motivasi guru untuk segera ikut sertifikasi bukanlah untuk meningkatkan profesionalime atau kompetensi mereka tetapi terkesan semata-mata untuk mendapatkan tambahan penghasilan melalui tunjangan profesi.

Pendidikan keorangtuaan adalah suatu pro ses yang disadari untuk mengembangkan potensi individu sehingga memiliki kecerdasan pikir, emosional, berwatak dan berketerampilan untuk siap hidup ditengah-tengah masyarakat. Peran keluarga sangat penting karena pengaruh utama perkembangan anak berasal dari lingkung an keluarganya. Oleh karena itu, orang tua sebagai orang yang terdekat dengan anak memp unyai peran penting dalam pemberian rangsangan (stimulasi) terhadap perkembangan a nak, sehingga perlu diperdayakan. Meski bagaimanapun karena setiap anak unik dan tidak ada yang sama satu dengan lainnya sekalipun kembar identik dan dalam satu keluarga, maka 
masing-masing anak berbeda tahap perkembangannya. Maka orangtua harus tetap waspada apabila keterlambatan jauh tertinggal dari pada umumnya.

Menurut Don Campbell dalam Fahruddin.dkk (2017) bahwa anak pada tahun awal perkembangan, otak anak dipengaruhi oleh keadaan atau situasi di sekelilingnya. Anak memasuki tingkat pendidikan selanjutnya juga tidak terlepas dari pengalaman awal yang sudah melekat dalam diri anak yang diperoleh dari hasil melihat orang tuanya, karenanya orang tua merupakan pendidik utama dalam keluarga. Apa yang dilakukan anak sebagian besar merupakan perilaku imitasi orang tuanya.

Lebih lanjut Wibowo dalam Fahruddin \& Zulfakar (2018) Lembaga pendidikan anak usia dini berupaya mengembangkan potensi yang dimiliki anak, dimana potensi tersebut memiliki keberagaman sesuai dengan karakteristik anak usia dini berdasarkan tahapan usia perkembangannya. Potensi yang dimiliki anak berbeda satu sama lain, sehingga membutuhkan pembelajaran yang berbeda pula. Pembelajaran yang diberikan harus mampu mengoptimalkan potensi yang ada agar dapat dimanfaatkan sebagai keterampilan hidupnya

Pembelajaran di lembaga PAUD tidak boleh melupakan pengalaman awal seorang anak yang sudah diperolehnya dari pendidkan dalam keluarga yaitu berasal dari kedua orangtuanya. Latar belakang pendidikan keluarga inilah juga harus menjadi pertimbangan dalam mengembangkan potensi anak dimana tidak keluar dari sebuah tujuan mempersiapkan anak memiliki kepribadian dan karakter yang positif. Anak-anak membangun pengetahuan dengan berinteraksi dengan orang lain menurut Inhelder dan Piaget Vygotsky dalam Fahruddin, dkk. (2018)

Proses membangun karakter dan kepribadian positif pada seorang anak ibarat mengukir atau memahat jiwa sedemikian rupa, sehingga "berbentuk" unik, menarik, dan berbeda antara satu dengan yang lain. Dengan demikian, dalam mendidik karakter setiap anak memliki potensi untuk berperilaku positif atau negatif. Jika orang tua dalam pendidikan keluarga membentuk pengalaman awal karakter positif sejak usia dini, maka yang berkembang adalah perilaku positif tersebut. Jika tidak, tentu yang akan terjadi sebaliknya. Uraian diatas dapatlah kita tarik benang merah antara pendidikan keluarga yang berasal dari kedua orang tua merupakan bentuk sinergi yang harus dibangun dengan pihak lembaga PAUD yaitu khususnya guru. Tujuan sinergi ini kemudian memunculkan ide dengan adanya sebuah program 'parenting'. Program parenting ini sebagai jembatan penghubung antara orang tua dan guru di sekolah dalam upaya mengembangkan potensi yang bersifat positif agar terbentuknya generasi bangsa yang berkarakter tidak hanya memiliki kepandaian/pengetahuan saja.

Kompetensi guru profesional meliputi kemampuan guru mengenal peserta didik yang dilayaninya secara mendalam, menguasai bidang studi secara keilmuan dan kependidikan dalam hal mengemas materi pembelajaran, kemampuan menyelenggarakan pembelajaran yang mendidik mulai dari perancangan sampai pemanfaatan hasil penilaian terhadap proses dan hasil pembelajaran serta pengembangan profesionalitas yang berkelanjutan. Namun beberapa hasil penelitian memperlihatkan motivasi guru untuk segera ikut sertifikasi bukanlah untuk meningkatkan profesionalime atau kompetensi mereka tetapi terkesan semata-mata untuk mendapatkan tambahan penghasilan melalui tunjangan profesi.

Pendidikan pada anak usia dini merupakan pendidikan yang paling mendasar bagi tumbuh kembang anak. Pada usia dini terjadi pertumbuhan dan perkembangan anak yang sangat pesat terutama dalam proses pembentukan dasar-dasar potensi dan kecerdasan anak. Perkembangan potensi dasar anak mencapai $80 \%$ pada usia dini, sementara sisanya terjadi sampai anak mencapai masa remaja akhir atau pada usia 17/18 tahun. Kondisi ini perlu mendapat perhatian yang serius bila menginginkan tumbuhnya generasi emas atau generasi yang berkualitas dikemudian hari. Kualitas sumber daya manusia sangat ditentukan oleh stimulasi yang diterima anak pada saat tumbuh kembang di usia dini. Stimulasi diberikan untuk mengembangkan potensi dasar yang dimiliki anak sehingga perkembangannya menjadi optimal. Perkembangan potensi dasar yang terjadi pada anak usia dini adalah mencakup perkembangan dasar-dasar kepribadian dan karakter anak, yang tentu saja akan memberikan warna kepribadian dan karekater anak pada usia selanjutnya.

Pendidikan anak usia dini dilakukan melalui bermain. Dengan bermain stimulasi terhadap anak akan menyentuh seluruh aspek perkembangannya. Dan yang lebih utama adalah 
proses pembelajaran terhadap anak akan menyenangkan. Hal ini akan mendorong percepatan terhadap perkembangan itu.

Konsep pengembangan ini harus dipahami oleh para pendidik dan orang tua. Karena orangtua maupun para pendidik PAUD selalu berharap agar anak atau anak didiknya akan mampu mencapai prestasi dan tumbuh kembang secara optimal. Untuk menopang tumbuh kembang potensi dasar, dasar-dasar kepribadan dan karakter anak, para pendidik dan orang tua mesti sinkron dalam mendidik anak. Walaupun tidak mudah menjalin kerjasama antara orang tua dan pendidik. Orang tua maupun pendidik sering tidak mempunyai pandangan yang sama terhadap pendidikan, khususnya dalam mendisiplinkan anak, hubungan antara orang tua dan anak, anak laki-laki dan perempuan, budaya, dan cara belajar anak usia dini Patmonodewo dalam Jurnal Zulfakar\&Fahruddin (2018). Partisipasi orang tua sangat dibutuhkan guna mencapai perkembangan yang optimal.

Namun pada kenyataannya hal ini sulit dilakukan. Seringkali orang tua tidak sejalan dengan program yang dilakukan oleh sekolah. Misalnya dalam pengembangan kemampuan baca tulis hitung orang tua tidak memahami program yang dilakukan oleh sekolah. Tuntutan orang tua untuk perkembangan ini sangat besar dan inginnya dilakukan secara instan. Sehingga tidak jarang orang tua mengeleskan anaknya untuk baca tulis hitung di luar sekolah dengan metode yangberbeda dengan di sekolah. Hal ini justru dapat berakibat sebaliknya, karena anak mengalami kebingungan.

Adapun dalam konsep pendidikan agama Islam tentang Parenting (pengasuhan) memiliki landasan yang pasti, yaitu Al-Quran. Dalam Surah At-Tahrim ayat 6 Allah SWT berfirman: Hai orang-orang yang beriman, peliharalah dirimu dan keluargamu dari api neraka yang bahan bakarnya adalah manusia dan batu; penjaganya malaikatmalaikat yang kasar, keras, dan tidak mendurhakai Allah terhadap apa yang diperintahkanNya kepada mereka dan selalu megerjakan apa yang diperintahkan.

Dengan demikian untuk menganalisis persoalan-persoalan yang terjadi, dibutuhkan suatu program parenting di sekolah yang dapat mensinkronkan program sekolah dan di rumah. Jika program stimulasi terhadap anak dilakukan secara berkelanjutan maka perkembnagan yang optimal akan dapat dicapai.

\section{Peran pendidikan anak usia dini}

Pendidikan Anak usia dini merupakan uapaya yang sistematik dan terencana untuk menstimulasi tumbuh kembang anak yang berusia antara 0-6 tahun (UU no 20 tahun 2003 tentang Sisdiknas). Stimulasi tumbuih kembang anak usia dini mencakup upaya pengembangan aspek perkembangan atau domain, afeksi, seni, kognitif, bahasa, sosial, fisik, pembangunan, dan bermaian peran secara simultan dan berkesinambungan pada anak usia dini. Pembinaan atau stimulasi dilakukan lewat belajar melalui bermain. Atau aktifitas bermain dilakukan oleh anak yang fasilitasi dan didampingi oleh oleh guru sehingga terjadi proses belajar untuk stimulasi domain atau aspek perkembangan anak secara simultan dan optimal.

Sesuai dengan UU No 20 tahun 2003, tentang Sisdiknas, menyebutkan pendidikan anak usia dini diselenggarakan sebelum jenjang pendidikan dasar, melalui jalur formal, nonformal, dan informal. Pada jalur forma bentuknya taman kanak-kanak (TK), Raudhatal Athfal (RA), dan bentuk lainnya yang sederajat. Sementara pada jalur nonformal berbentuk, Kelompok Bermain (KB), Taman Penitipan Anak (TPA), atau bentuk lainnya yang sederajat.

Dalam rangka peningkatan mutu pendidikan anak usia dini mengalami berbagai permasalahan antara lain adalah kerjasama orang tua dan para pendidik. Patmonodewo (2003) mengemukakan tidak mudah menjalin kerjasama antara orang tua dan pendidik. Orang tua maupun pendidik sering tidak mempunyai pandangan yang sama terhadap pendidikan, khususnya dalam mendisiplinkan anak, hubungan antara orang tua dan anak, anak laki-laki dan perempuan, budaya, dan cara belajar anak usia dini.

\section{a. Bekerja sama dengan orang tua murid}

Rumah dan orang-orang yang tinggal di dalamnya menjadi bagian yang sangat penting dari kehidupan anak (Papalia, 2010). Dan orang tua adalah sosok yang penting dalam perkembangan identitas anak (Santrock, 2007)

Baik orang tua maupun pendidik selalu berharap agar anak didiknya akan mampumencapai prestasi dan tumbuh kembang yang optimal. Walaupun tidak mudah menjalin kerjasama antara 
orang tua dan pendidik. Orang tua maupun pendidik sering tidak mempunyai pandangan yang sama terhadap pendidikan, khususnya dalam mendisiplinkan anak, hubungan antara orang tua dan anak, anak laki-laki dan perempuan, budaya, dan cara belajar anak usia dini (Patmonodewo 2003). Untuk itu partisipasi orang tua di sekolah dan terhadap program sekolah sangat dibutuhkan.

Kemungkinan keterlibatan orangtua (Morrisson dalam Patmonodewo, 2003) di sekolah berorientasi pada tugas, proses, dan perkembangan. Orientasi pada tugas yaitu terkait dengan keterlibatan orang tua dalam membantu program sekolah, yang berkaitan dengan staf pengajar, staf administrasi, sebagai tutor, melakukan monitoring, membantu mengumulkan dana, membantu mengawasi apabila anak-anak melakukan kegiatan kunjungan luar. Orientasi pada proses adalah orangtua didorong untuk terlibat pada kegiatan yang berhubungn dengan proses pendidikan, antara lain perencanaan kurikulum, memilih buku yang akan digunakan, menentukan standar tingkah laku yang diharapkan, dan lain-lain. Hal ini masih sangat jarang ditemukan. Orientasi pada perkembangan yaitu untuk membantu orangtua dalam mengembangkan keterampilan yang berguna bagi mereka, anak-anaknya, sekolah, pendidik, dan pada waktu yang sama meningkatkan keterlibatan orang tua di sekolah.

Fahruddin, dkk. (2017) menerangkan bahwa konsep pengasuhan mencakup beberapa pengertian pokok, antara lain: (1) pengasuhan bertujuan untuk mendorong pertumbuhan dan perkembangan anak secara optimal, baik secara fisik, mental, maupun sosial, (2) pengasuhan merupakan sebuah proses interaksi yang terus menerus antara orangtua dengan anak, (3) pengasuhan adalah sebuah proses sosialisasi, (4) sebagai sebuah proses interaksi dan sosialisasi, proses pengasuhan tidak bisa dilepaskan dari sosial budaya dimana anak dibesarkan. Dengan demikian, maka pengasuhan dan pendidikan dalam keluarga adalah merupakan inti dan fondasi dari upaya pendidikan secara keseluruhan.

Armsden, G.C., \& Greenberg, M.T. (1987) percaya bahwa keterlibatan orang tua di sekolah akan meringankan guru dalam membina kepercayaan diri anak, mengurangi masalah disiplin anak, dan meningkatkan motivasi anak. Sedangkan Henderson \& Mapp. (2002) menemukan beberapa hal yang berkaitan dengan keterlibatan orang tua, yaitu sebagai berikut:

1) Lingkungan keluarga, bukan lingkungan sekolah, merupakan lingkungan belajar anak yang pertama

2) Keterlibatan orang tua dalam pendidikan formal anak akan meningkatkan prestasi di sekolah

3) Keterlibatan orang tua di sekolah akan lebih efektif apabila terencana dengan baik dan berjalan dalam jangka waktu yang panjang

4) Keterlibatan orang tua sebaiknya dilakukan sedini mungkin dan berkelanjutan

5) Keterlbatan orangtua terhadap pendidikan anakanak di rumah belum cukup. Meningkatnya prestasi anak baru tampak apabila orangtua melibatkan pendidikan anak di sekolah

6) Anak-anak yang berasal dari keluargatidak mampu serta minoritas akan menunjukkan peningkatan prestasi apabila orangtua terlibat dalam kegiatan anak, walaupun pendidikan orang tua berbeda sekalipun.

Dari uraian tersebut, tampaklah bahwa keterlibatan orang tua dalam pendidikan anaknya, di rumah ataupun di sekolah dibutuhkan untuk pencapaian prestasi dan perkembangan anak.

Keuntungan bagi pihak sekolah yang diperoleh dengan adanya keterlibatan orang tua adalah sebagai berikut:

1) Mempelajari bagaimana orang tua memotivasi anaknya

2) Melihat bagaimana anggota keluarga menolong anaknya dalam memecahkan masalah

3) Mempelajari tindakan budaya yang berbedabeda

4) Mempelajari keterampilan khusus dan hobby yang sama-sama dimiliki anak dan anggota keluarga

5) Berkembang iklimuntuk merencanakan dan memecahkan masalah bersama

6) Orang tua dan pendidik lebih memahami perilaku anak

7) Kehadfiran orang tua membantu mengindividualisasi kegiatan dan memperkaya kelas

8) Membantu komunikasi rumah-sekolah dan menghindari berbagai halangan (Ali, 2008)

Sedangkan keuntungan bagi pihak orang tua yang diperoleh dengan adanya keterlibatan orang tua di sekolah adalah sebagai berikut: 
1) Mengembangkn rasa memiliki program

2) Belajar melihat bagaimana anakberhubungan dengan orang lain

3) Lebih memahami perkembangan anak

4) Mengetahui dan menghargai para pendidik

5) Mempelajari kegiatan yang menyenangkan untuk dipelajari di rumah

6) Bertemu dengan teman-teman anaknya

7) Membangun persahabatan dengan orang tua lain

8) Dapat mendukung pembelajaran di rumah

(Ali, 2008)

Lebih lanjut kalau kita berbicara tentang parenting dalam Islam (Laelatul, 2015) atau yang disebut Islamic Parenting adalah mempersiapkan generasi muda yang memiliki moral yang mengacu pada norma-norma Islam dan membentuk generasi yang shahlih dan shalihah. Pendidikan dalam Islam dimulai sebelum anak lahir di dunia, bukan hanya ketika anak sudah lahir. Konsep Iskamic Parenting mengajarkan pola asuh yang digunakan orangtua juga mencakup bagaimana orangtua mampu membentuk akhlakul karimah terhadap anakanaknya.

Bentuk-bentuk kerjasama yang dapat dilakukan antara orang tua dan pihak sekolah/PAUD dan pendidik antara lain adalah: Bentuk kerjasama sekolah dan orangtua yang dapat dilakukan menurut Epstein (dalam Coleman, 2013) yaitu: parenting, komunikasi, volunteer, keterlibatan orangtua pada pembelajaran anak di rumah, pengambilan keputusan,

dan kolaborasi dengan kelompok masyarakat. Vaden-Kierman dan McManus (dalam Patrikakou, 2008) menyatakan bahwa keterlibatan orangtua dalam pendidikan mempunyai berbagai macam tingkatan mulai dari bentuk sederhana yaitu menanyakan kemajuan anak di sekolah, partisipasi dalam evaluasi program, dan pembuatan keputusan dalam program

\section{Metode Penerapan}

Kegiatan Pengabdian dengan tema Pelatihan Program Parenting untuk Meningkatkan Profesionalisme Guru PAUD/TK di Kota Mataram padadasarnya dilaksanakan dengan metode memberikan pendidikan dan pelatihan. yang bervariasi, antara lain: Penyuluhan dan komunikasi, Setelah kegiatan ini dilaksanakan diadakan rehat sejenak yang berisi Tanya jawab dan diskusi berkaitan tentang materi pelatihan. Kegiatan selanjutnya dilakukan dengan Pendampingan membuat program parenting bagi guru PAUD/TK yang ada di kota Mataram berupa pemberian tugas membuatatau menyusun program parenting untuk meningkatkan profesionalisme guru dalam pengasuhan anak usia dini. Kegiatan pendampingan juga untuk bagaimana dalam mengimplementasikan program parenting yang telah dibuat pada lembaga PAUD/Tk yang ada di kota mataram. Pelatihan penyuluhan program parenting lebih ditekankan pada peningkatan pemahaman berkait dengan konsep program parenting. Pelatihan diterapkan dalam peningkatan keterampilan pendidik PAUD dalam pengembangan program parenting untuk meningkatkan profesionalisme guru PAUD/TK.

\section{Hasil dan Pembahasan}

Sasaran dari pengabdian kepada masyarakat ini adalah para pendidik atau guru PAUD yang mengajar di PAUD/ TK di Kota Mataram yang terdiri dari beberapa lembaga PAUD/ Tk diwilayah Kota Mataram. Adapun peserta pelatihan ini berasal dari lembaga PAUD/TK yang berada di Gugus 3 wilayah Kota Mataram. Hasil pelatihan pengabdian ini diharapkan terus dikembangkan dan diimplementasikan secara konsisten oleh guru atau pendidik yang telah mengikuti pendidikan dan pelatihan. Agar tercapai hal tersebut kegiatan pendidikan dan pelatihan ini melibatkan instansi terkait diantaranya adalah Pengurus Gugus 3 wilayah kota mataram, pengurus Himpaudi Kota Mataram dari Dinas Pendidikan Kota Mataram.

Realisasi untuk membantu memecahkan masalah yang dihadapi oleh pihak lembaga PAUD / TK di Gugus 3 Wilayah Kota Mataram, tim pengabdian memberikan gambaran praktis mengenai penyusunan rancangan pembuatan program parenting dan keterampilan dalam mengembangkan program parenting.

Adapun kegiatan dalam pengabdian ini, kami mengadakan pelatihan dalam perancangan program parenting dan keterampilan dalam mengembangkan program parenting, untuk meningkatkan profesionalisme Guru PAUD dengan menberikan pelatihan pembuatan tentang kegiatan/program yang sesuai dengan lingkungan 
lembaga masing-masing untuk bisa diterapkan materi dari pelatihan. Selanjutnya, Keterampilan dalam mengembangkan program parenting untuk bisa mengarahkan bagaimana cara penyusunan program parenting yang telah dipilih.

Program parenting yang bisa di kembangkan dilembaga PAUD/TK yaitu program parenting seperti: Program Parenting untuk Anak Usia Dini / TK. Program Parenting atau Program PAUD Berbasis Keluarga adalah salah satu upaya keselarasan dan keberlanjutan pendidikan yang dilakukan di rumah.

Program Parenting di Lembaga Pendidikan Anak Usia, yaitu di antaranya

1. Kegiatan pertemuan orangtua ( parenting class)

Kelas orangtua merupakan wadah komunikasi bagi orangtua dengan pengelola PAUD maupun guru. Jenis kegiatannya seperti dibentuk arisan orangtua dan guru agar terjalin intensitas pertemuan yang rutin, membuat grup parenting di sosial media seperti di WA, FB, BBM,dll. Pertemuan rutin di setiap bulan dengan beragam tujuan.

2. Keterlibatan orangtua dalam kelas

Lembaga PAUD harus sesekali melibatkan orangtua dalam kelas seperti bermain dan bermain bersama anak seperti mewarnai gambar, meronce, membuat kolase, dan lainnya. Sekolah juga dapat melaksanakan perlombaan ibu dan anak untuk memperingati hari - hari besar

3. Keterlibatan orangtua dalam acara bersama

Kegiatan bermain dan belajar yang merupakan proses kegiatan pembelajaran bagi anak tidak harus selalu di dalam kelas. Sesekali di luar kelas bahkan di luar sekolah. Orangtua harus dilibatkan sehingga orang tua dapat mengetahui bagaimana perkembangan anak dan dapat mengarahkan perkembangan tersebut secara optimal. Kegiatannya seperti menghadiri seminar pendidikan atau parenting, rekreasi bersama, mengikuti beragam perlombaan di luar sekolah, dan lainnya.

4. Hari konsultasi orangtua

Pengelola PAUD sebaiknya juga menjadwalkan hari - hari tertentu dimana orangtua, pengelola, dan pendidik dapat bertatap muka dan bermusyawarah untuk membahas tumbuh kembang anak, masalah masalah yang dihadapi, dan solusi untuk mengatasi setiap permasalahan. Jika perlu pengelola PAUD dapat menghadirkan seorang ahli di bidang pendidikan, kesehatan, dan kejiwaan anak. Hal ini dapat dilaksanakan melalui kemitraan dengan pihak terkait seperti puskesmas, Dinas Pendidikan setempat, dan Instansi lainnya.

5. Kunjungan rumah (home visit)

Sesekali pengelola PAUD dan pendidik dapat mengunjungi rumah peserta didik untuk menjalin silaturahim dan memupuk ikatan kekerabatan.

$\begin{array}{crr}\text { Keterampilan } & \text { dalam melaksanakan } \\ \text { program parenting } & \text { untuk } & \text { meningkatkan }\end{array}$ profesionalisme guru PAUD/Tk di wilayah Kota Mataram bisa berjalan dengan baik jika mengacu atau melaksanakan program yang sudah di berikan dalam pelatihan dan pengabdian masyarakat. Namun kemampuan dalam mengembangkan dan strategi dalam pembuatan program parenting untuk meningkatkan profesionalisme guru PAUD/TK belum dimiliki oleh guru. Program parenting yang ada disekolah dibuat oleh pihak yayasan dan komite. Kemudian diserahkan kepada pihak sekolah dan diterapkan sesuai dengan rancangan yang sudah ditetapkan tersebut. Oleh sebab itu, pihak sekolah tidak membuat rancangan parenting melainkan melaksanakan jadwal kegiatan parenting yang sudah ditetapkan tersebut.

Berdasarkan hasil kegiatan pelatihan dan pendampingan yang diberikan para peserta mendapatkan pengetahuan mengenai bagaimana menyusun rancangan kegiatan program parenting untuk meningkatkan profesionalisme guru PAUD/TK di Kota Mataram. Faktor-faktor pendorong dan penghambat pelaksanaan pelatihan dan pendampingan:

a. Faktor pendorong pelaksanaan pelatihan

- Adanya dukungan dari pihak lembaga menyediakan tempat untuk pelaksanaan pelatihan dan mengkoordinir pelaksanaan pelatihan dan peserta pelatihan.

- Terjalinnya kerjasama antara tim pengabdian dan seluruh peserta pelatihan di PAUD/Tk Gugus 3 wilayah kota Mataram.

- Selama kegiatan berlangsung para peserta banyak memberikan apresiasi.

- Para pesera aktif mengikuti kegiatan pelatihan dari awal hingga akhir, hal ini ditunjukkan dengan banyaknya pertanyaan dan diskusi materi yang belum di pahami.

b. Faktor penghambat 
Selama kegiatan berlangsung kegiatan pengabdian di gugus 3 wilayah kota mataram, tim pengabdian tidak menjumpai adanya hambatan baik secara administrasi maupun teknis, dikarenakan terjalinnya komunikasi yang baik antara lembaga dan pihak tim pengabdian dari PG PAUD FKIP Universitas Mataram

\section{Simpulan dan Saran}

\section{Simpulan}

Melalui pelatihan dan pendampingan mengenai penyusunan program Parenting untuk meingkatkan profesionalisme guru PAUD/TK di Kota Mataram terlihat bahwa para peserta sebagian besar sudah mampu untuk menyusun program Parenting dalam mengembangkan program parenting. Dibutuhkan motivasi untuk terus mempraktekkan di dalam menyusun keterampilan mengembangkan program parenting di PAUD / TK sehingga semua guru maupun kepala sekolah mengetahui dan memahaminya.

Kesadaran orang tua dan guru PAUD dalam mendidik anak terutama dalam hal pembimbingan dan pngasuhan Orang tua dan guru memperoleh model agar menjadi orang tua dan guru yang baik dalam mendidik anak. Orang tua dan guru dapat menciptakan iklim pengasuhan yang demokrasi. Pencerahan dalam mendidik dan mendampingi anak PAUD menjadi kebutuhan yang mendasar bagi orang tua agar selalu ingat bahwa pengalaman semasa Usia dini menjadi dasar yang paling penting untuk pertumbuhan dan perkembangan selanjutnya. Lembaga PAUD yang sukses bisa melibatkan orang tua dalam melakukan kegiatan yang mendukung program sekolah. Program parenting penting untuk menjembatani program dan perlakuan yang berkesinambungan antara di rumah dan di sekolah.

\section{Saran}

Mengingat semakin berkembangnya lembaga pendidikan formal maupun non formal di Mataram, maka diharapkan para pengelola berupaya untuk menyediakan sarana dan prasana dalam pembuatan program parenting dan untuk mengembangkan keterampilan guru dalam penerapannya di sekolah. Tentunya disarankan kepada : a) Orang Tua: sebaiknya tetap menjadi orang tua yang dapat dijadikan Model bagi anak- anaknya, karena anak masih meniru yang menjadi idolanya, b) Bagi Guru: diperlukan komitmen yang tinggi dalam melaksanakan tugas dalam mendidik anak sejak dini, terutama diperlukan guru yang mampu menberikan bimbingan kepada anak, c) Bagi lembaga: hendaknya menberikan dukungan dan motivasi dalam pelaksanaan kegiatan parenting di lembaga PAUD terutama dalam penyediaan fasilitas dan media pembelajaran yang memadai untuk meningkatkan potensi anak.

\section{Daftar Pustaka}

Armsden, G.C., \& Greenberg, M.T. 1987. The inventory of parent and peer attachment: Relationships to well-being in adolescence. Journal of Youth and Adolescence. 5, 427454.

Ali Nugraha, dkk, Metode Pengembangan Sosial Emosional, Universitas Terbuka, 2006

Coleman, M. 2013. Empowering Family-Teacher Partnership Building Connections within Diverse Communities. Los Angeles: Sage Publication.

Fahruddin, dkk. 2017. Efektifitas Parenting Dalam Peningkatan Proses Stimulasi Tumbuh Kembang Anak di PAUD/TK kota mataram. Laporan Penelitian PNBP Unram.

Fahruddin \& Zulfakar. 2018. Culturally Responsive Teaching Practice In Early Childhood, International Journal of Recent Scientific Research Research. Vol. 9, Issue, 9(E), pp. 28941-28951.

Henderson \& Mapp. 2002. National Standards for Parent/Family Involvement Programs

Papalia E\& Olds. 2010. Human Development, Boston: McGraw - Hill International Edition.

Patmonodewo, S. 2003. Pendidikan Anak Prasekolah. Jakarta: PT. Asdi Mahasatya 
Patrikakou, E. N. 2008. The Power of Parent Involvement: Evidence, Ideas, and Tools for Student Success. http://education.praguesummerschools.org/i mages/education/readings

Robbins, Stephen R. 1978. Organizational, Behaviour, Concept, Controversies, Aplications, Boston : Finish Association of Designers.

Robert E Slavi., 2005. Cooperative Learning London: Allynman, Bacon.

Santrock W. 1997. Life Span Development, University of Texas - Dallas. Times Mirror Higher Education Group

Lajnah Pentashihan Al-Quran Kementerian Agama republic Indonesia, 2010. Al-Quranul dan terjemahan, (Badung: Jbal Raudhatul Jannah.

Laelatul Fajriah. 2015. Studi tentang Islamic Parenting di Desas Linggapura Kecamatan Tonjong kabopaten Brebes", Fakultas Dakwah dan Komunikasi UIN Sunan KAllijaga.

Muhammad Fadlillah. 2012. Desain Pembelajaran PAUD, Yogyakarta, Ar-Ruzz. 